\title{
Gestão dos resíduos de manejo arbóreo em São Paulo
}

\author{
Fernanda Soliga Voltam \\ Divisão de Arborização Urbana - Secretaria do Verde e do Meio Ambiente / PMSP \\ Especialista em Gestão Pública e Controle Externo \\ fsvoltam@prefeitura.sp.gov.br
}

\section{RESUMO}

O Município de São Paulo acaba de elaborar o Plano Municipal de Arborização Urbana que é o instrumento de definição do planejamento e da gestão da arborização, com diretrizes para repensar a arborização desde inovações no plantio à destinação de resíduos, visando o aumento da resiliência da cidade às mudanças climáticas, a qualificação da paisagem e a satisfação da população.

Palavras-chave: plano municipal, arborização urbana, gestão, resiliência.

\begin{abstract}
The Municipality of São Paulo has just prepared the Municipal Plan for Urban Arborization, which is the instrument for defining the planning and management of afforestation, with guidelines for rethinking afforestation, from innovations in planting to the destination of waste, aiming at increasing the city's resilience. climate change, landscape qualification and population satisfaction.
\end{abstract}

Keywords: municipal plan, urban afforestation, management, resilience. 